University of Nebraska - Lincoln

DigitalCommons@University of Nebraska - Lincoln

University of Nebraska Press -- Sample Books

and Chapters

University of Nebraska Press

Spring 2013

Mysteries of the Jaguar Shamans of the Northwest Amazon

Robin M. Wright

Follow this and additional works at: https://digitalcommons.unl.edu/unpresssamples

Wright, Robin M., "Mysteries of the Jaguar Shamans of the Northwest Amazon" (2013). University of Nebraska Press -- Sample Books and Chapters. 198.

https://digitalcommons.unl.edu/unpresssamples/198

This Article is brought to you for free and open access by the University of Nebraska Press at DigitalCommons@University of Nebraska - Lincoln. It has been accepted for inclusion in University of Nebraska Press -- Sample Books and Chapters by an authorized administrator of DigitalCommons@University of Nebraska - Lincoln. 
Mysteries of the JAgUAR SHAMANS of the Northwest Amazon 


\section{MYSTERIES of the}

JAGUAR SHAMANS

of the Northwest Amazon

Robin M. Wright | Foreword by Michael J. Harner 
(C) 2013 by the Board of Regents of the University of Nebraska All rights reserved Manufactured in the United States of America

Publication of this volume was assisted by the Virginia Faulkner Fund, established in memory of Virginia Faulkner, editor in chief of the University of Nebraska Press.

$\infty$

Library of Congress

Cataloging-in-Publication Data

Wright, Robin, I950-

Mysteries of the jaguar shamans of the northwest Amazon / Robin M. Wright; foreword by Michael J. Harner.

pages. $\mathrm{cm}$

Includes bibliographical references and index.

ISBN 978-0-8032-4394-I (cloth: alk. paper) I. da Silva, Mandu. 2. Baniwa Indians-Biography. 3. ShamansBrazil-Biography. 4. Baniwa Indians-Religion. 5. Baniwa philosophy. 6. Baniwa Indians-Rites and ceremonies. I. Title.

F 2520.I.B35D3 20I3

$299^{\prime} .8839-\mathrm{dc} 23 \quad 2013001790$

Set in Sabon Next by

Laura Wellington.

Designed by Nathan Putens. 


\section{Contents}

List of Illustrations vii

Foreword ix

Acknowledgments $x i$

Introduction $I$

Part I. Shamans, Chanters, Sorcerers, and Prophets

I "You Are Going to Save Many Lives":

The Life Story of Mandu da Silva, Hohodene

Jaguar Shaman, coauthored by Manuel da

Silva and Ercilia Lima da Silva $3 I$

2 Mandu's Apprenticeship and a Jaguar

Shaman's Powers of World-Making 53

3 "You Will Suffer Along Our Way":

The Great Suffering in Mandu's Life 105

Part 2. Shamanic Knowledge and

Power in the Baniwa Universe

4 Creation, Cosmology, and Ecological Time $\quad$ I47

5 Mythscapes as Living Memories of the Ancestors 208 
Part 3. Transmission of Shamanic Knowledge and Power

6 The Birth of the Child of the Sun, Kuwai 233

7 Death and Regeneration in the First Initiation Rites, Kwaipan 247

8 The Struggle for Power and Knowledge among Men and Women 276

Part 4. Revitalization Movements in Traditional and Christianized Communities

9 The House of Shamans' Knowledge and Power, the House of Adornment, and the Pamaale School Complex 297

Conclusion 325

Appendix I. Letter Authorizing Reproductions of Kuwai-ka Wamundana 337 Appendix 2. Description of The Mysterious Body of Kuwai 339

Notes 343

Bibliography 353

Index 365 


\section{Illustrations}

FIGURES

I Aerial view of Uapui (Hipana) falls, the origin of the universe 5

2 Mandu at the height of his powers in $1977 \quad 44$

3 Mandu and José Garcia 47

4 “Old pajé José” Cornélio 49

5 Mandu and wife, Flora, at their home in São Gabriel 52

6 Jaguar shamans on their journey in the Other World 55

7 José Garcia extracting pain and sickness from author's leg 58

8 Pot of pariká in preparation 64

9 Shaman's rattle 90

Io Drawing of sacred flutes on shaman's rattle 92

II Mandu and his apprentices, 20I0 104

I2 Dyuremawa Maloca on the upper Aiary River, $1927 \quad 108$

I3 Tomb of the prophet Kudui on Warukwa Island 138

I4 Kaxadadali 163

I5 The universe (Hekwapi), according to José Garcia $\quad$ I69 
I6 Wamu (black sloth) with stains on its pelt $\quad$ I88

I7 Reproduction of petroglyphs on boulder of "false Kuwai" at Hipana Rapids $2 I I$

I8 Petroglyphs at Hipana $2 I 2$

I9 Petroglyph of Kuwai at Pukweipan 213

20 Reproduction of petroglyphs at Ehnípan 214

2I Two Hohodene chanters in characteristic postures of chanting 29I

22 The Sacred Boulder of Dzuliferi, Spirit of Power 292

23 Laureano and young men during Ukuki initiation ceremony 313

24 Young women at the inauguration ceremony for the Malikai Dapana $32 I$

25 Drawing of Kuwai-ka Wamundana by jaguar shaman Luiz Gomez 340

MAPS

I Northern Arawak-speaking peoples in the Northwest Amazon 3

2 Mythscape of the Northwest Amazon 209

TABLES

I Religious specialists of northern Arawakan Baniwa 8

2 Prophetic traditions of the Northwest Amazon 139 


\section{Foreword | Michael J. Harner}

Since the seventies, Robin Wright has immersed himself in the study of the shamanic practices of the Baniwa of Northwest Amazonia. In this book-much of which is seen through the eyes of the elder jaguar shaman and "wise man" or prophet of his people, Manuel "Mandu" da Silva-the ancient ways of the Baniwa shamans come to life, not only for scholars but in a way that will be familiar to anyone who has practiced contemporary shamanism.

Dr. Wright is my kind of anthropologist. In this writing his scholarship is meticulous, and as a scientist he maintains an attitude of objective inquiry, yet he probes beneath the surface of the shamanic practices described, observed, and experienced to see what is actually happening. He does not merely study and record the spiritual practices of a people, but recognizes that their shamanic traditions, centuries old, have persisted precisely because they have worked for the people. The shamans' knowledge is valued and treated with the respect it deserves.

What emerges from Mysteries of the Jaguar Shamans of the Northwest Amazon is an intimate and fascinating portrait of the spiritual heart of a people. The story begins with a look at Mandu's shamanic training and apprenticeship through a rare telling in the shaman's own words. It continues with the trials he faced and the successes he achieved during a lifetime of work as a healer and as a carrier of, and an advocate for, his people's traditional ways, which he recognizes are essential to the cultural survival of his people. 
The remaining chapters encompass an entire shamanic tradition, including the problem of sorcery in the villages and Mandu's lifelong struggle against it; missionization and other challenges to the continuity of shamanic traditions; the interrelatedness of Baniwa cosmology, ecology, and shamanic knowledge and power; and the significant role of the ancestors, as revealed and preserved in the memories of the elders, chants, living myths, and a landscape of sacred places and petroglyphs.

The last chapter is devoted to describing the continuing efforts of Mandu, now in his late eighties, and his daughter Ercilia and son Alberto, to revitalize, "valorize" as they term it, Baniwa traditions and preserve them for future generations. Dr. Wright has played an important role in seeking support for the revitalization project through public and private sources. In 2009, he contacted the Foundation for Shamanic Studies, which raised funds to build a village longhouse and help launch the Baniwa shamanic renaissance. The longhouse was intended as a place for the community to gather for cultural events and where traditional ways could be practiced and taught. The longhouse now serves as the House of Shamans' Knowledge and Power, Malikai Dapana, a school for a next generation of shamans. Mandu has several new apprentices seeking to learn the ancient mysteries of their jaguar shaman ancestors. Much more remains to be accomplished.

With Mysteries of the Jaguar Shamans of the Northwest Amazon, Dr. Wright makes a significant contribution to the understanding of the shamanic practices of the indigenous peoples of the region. But more than that, he has assured that the decades of spiritual knowledge and practices of Mandu da Silva, jaguar shaman and wise man of his people, will not be lost and will be available for the generations to come.

$\mathrm{x}$ Foreword 


\section{Acknowledgments}

To the most important of my teachers, Manuel "Mandu" da Silva, Hohodene jaguar shaman, his wife, Flora, and all of their family, phiume nukitchienape, more thanks than I can express, matchia hape. A ceramic vessel for beer, an ancient stone ax head, and shamanic knowledge and power are some of the lasting gifts and living memories I have received from Mandu and his family.

José Cornelio, jaguar shaman and paternal uncle of Mandu, taught me some of his extraordinarily detailed and extensive knowledge of shamans' power, with the invaluable assistance of his stepson, José Felipe, during my first field research in Uapui village in the 1970s. Today José Felipe has become an important pajé (shaman) of Uapui, carrying on his stepfather's and uncle's teachings and practice.

Mandu's wife, Flora, and their daughters, Anninha and Ercilia, are well versed in shamanic knowledge, chanting for initiation rites, and herbal remedies.

José Garcia, jaguar shaman and one of the last savants or wise men (sábios) among the Hohodene Baniwa, was another great teacher who, besides sharing some of the jaguar shamans' wisdom, healed my leg. But he left this world too early, before he had attained the greatness of his father, the sábio named Kudui.

I also had the good fortune to learn from Ricardo Fontes of Ukuki village and Marco of Santarém village, both highly respected "owners" of chants and dance masters. Their explanations and 
teachings of the Kuwai story only became clear many years after they too had left this world.

Ercilia de Lima da Silva, daughter of Mandu, was my research assistant in the field in 2009 and 2010, and she did an outstanding service by taping, filming, transcribing, and translating interviews with her father. If there now exists an extensive collection of taped and filmed material on Baniwa shamans of the Aiary River, it is due in large part to the collaboration of father and daughter in this project.

Isaias Pereira Fontes, kuekato, a young Hohodene man from Ukuki, also my research assistant, filmed and taped various dance festivals (including the initiation rite) and interviews with his uncle Laureano, son of Ricardo, and shaman grandfather Augusto. For many years, Isaias has shown a strong interest in documenting the traditions of his ancestors, and he holds great promise for producing something of lasting value for his people.

I wish to thank many other teachers and explainers of stories: Laureano Fontes (one of the few true mandero, dance leaders), João Fontes, and Augusto Fontes-all from Ukuki village and the same local descent group, known throughout the region for their knowledge and practice of traditional forms of shamanic healing and dance festivals.

Ercilia's brother, Alberto de Lima da Silva, conceived the idea of constructing a longhouse in his village of Uapui (or, in the Baniwa language, Hipana), where the revitalization of the old dance festivals and the transmission of shamanic knowledge could continue "with dignity." His idea was that "if no one does anything now, then the memory of ancient traditions of the pajés and of Kwaipan will die." With his family's support, the House was built and inaugurated in 2009.

Special thanks to Dr. Michael Harner, world recognized scholar and teacher of shamans and president of the Foundation 
for Shamanic Studies in California, and to Susan Mokelke, the Foundation's executive director, for their support in turning the project for constructing the House of Shamans' Knowledge and Power into a reality and for honoring Mandu da Silva with its Living Treasures award in 2009.

I must thank Dr. Omar González Ñáñez, el poeta, with whom I have long exchanged information and publications regarding the Arawak-speaking peoples and their religious traditions and to whom I am grateful for permission to publish a jaguar shaman's drawing of Kuwai-ka Wamundana, and Santiago Obispo, of Puerto Ayacucho, Venezuela, who provided contacts with researchers on the upper Guainia River.

Very special thanks to Dr. Elizabeth Reichel, who read early versions of this book and provided incentive with enormously helpful suggestions and many thoughtful criticisms. It was in no small part because of her strong interest and encouragement that the most difficult part of organizing this book was accomplished. Likewise, my colleague Manuel Vasquez, Department of Religion, University of Florida, made valuable suggestions and criticisms early on that I deeply appreciate.

Thanks to Carlos Xavier Leal, doctoral student at the Museu Nacional, UF RJ, in Brazil, for allowing access to his dissertation on the petroglyphs of the upper Içana and for the fruitful exchange of ideas on the meanings of the Kuwai story. Thanks also to my advisees who had important roles in completing this project: Marcio Meira, formerly president of the National Indian Foundation (FUNAI) in Brazil, was instrumental in the inauguration of the Malikai Dapana in 2009/10.

Dr. Maria Luiza Garnelo Pereira, with Fiocruz Amazonia, has published several excellent analyses on the health situation of the Upper Rio Negro, especially of the Baniwa on the Içana River. I thank her for her friendship, support, and insights into 
the ever-shifting political dynamics of contact in the Northwest Amazon. She graciously made available her notes, reports, and experiences of more than twenty years of fieldwork in the region. Yara Costa's M.A. research on dance festivals and music provided the first systematic ethnography of dance choreography of the Aiary River Baniwa.

A very special thanks and abraços fortes to my son, Michael, for his fine illustrations. Michael filmed the inauguration of the House of Shamans' Knowledge and Power. He designed folders for both the Malikai Dapana and the House of Adorning that can be seen on my URL (www.robinmwright.com). He has been an outstanding companion during field trips to the Upper Rio Negro since 1998; we were instructed together in some of the mysteries of the Baniwa cosmos. I thank my wife and daughter for their unbounded patience and understanding throughout the whole ordeal of producing this and other books.

I extend my gratitude to Bron Taylor for his wisdom, good company, good counsel, and friendship. The inspiration of his 2010 book, Dark Green Religion: Nature Spirituality and the Planetary Future, and his encouragement to me appear in numerous ways in this book.

Finally, to the many South Americanist colleagues, especially of the salsa (Society for the Anthropology of Lowland South America), who, in one way or another, over many years of exchanging ideas and participating in conferences together, were influential to this book: Renato Athias, Dominique Buchillet, Janet Chernela, Carlos Fausto, Mike Heckenberger, Jonathan Hill, Jean Jackson, Wolfgang Kapfhammer, George and Laura Mentore, Eduardo Neves, Augusto Oyuela-Caycedo, Joanna Overing, Fernando Santos-Granero, Lawrence Sullivan, Tod Swanson, Terrence Turner, Aparecida Vilaça, E. Viveiros de Castro, Neil Whitehead, Johannes Wilbert, and Eglee Zent.

xiv Acknowledgments 
To fellow Arawak scholars Fernando Santos-Granero, who evaluated the manuscript for the University of Nebraska Press, Neil Whitehead, in memorium, for his unfailing support, and Jonathan Hill, who generously provided many useful comments on pieces of the book all along the way, and to the anonymous peer reviewers, many thanks for your perceptive comments. Whatever errors that appear in this book are my own. 
Mysteries of the JAgUAR SHAMANS of the Northwest Amazon 


\section{Introduction}

This book explores the meanings of shamanic knowledge and power among the Baniwa, an Arawak-speaking indigenous people of the Northwest Amazon in Brazil, with whom I have worked since 1976. It focuses on the only living jaguar shaman among the Baniwa, Mandu da Silva of the village of Uapui, Aiary River, who has been a shaman for more than sixty-four years. The idea to write his biography came from his daughter, Ercilia, and Mandu gladly obliged. His narrative is the only one on record of a shaman who is today considered by many Baniwa to be a "wise man" (sábio in Portuguese; kanhenkedali in Baniwa), or what is referred to in the anthropology of religion as a prophet. By "prophet," I mean men and women believed to have the power to communicate constantly with the principal divinities, who advise them of things to come and of the attitude people should take in relation to those forthcoming events. Prophets are recognized by the culture as having the sole legitimate power to announce future events and warn of any imminent dangers.

The Baniwa people are well known in the literature for their history of engagement in religious movements of this nature (Wright and Hill 1986; Hill and Wright 1988; Wright 1998, 2005). Since the mid-nineteenth century, indigenous prophetic leaders have emerged in an almost continuous sequence among both Arawakspeaking peoples and Tukanoan-speaking peoples of the Northwest Amazon, on the borders of Brazil, Venezuela, and Colombia. On 
the history of these traditions, see my doctoral thesis, 198I; book, 2005; and numerous articles, 1983, 1992c, 2002a; also Hugh-Jones I98I, 1996).

Mandu's story is unique in that it reveals the struggles that a still-living jaguar shaman and sábio has faced during a lifetime dedicated to healing and counseling the people of the Northwest Amazon region. Like his predecessors, Mandu has demonstrated deep concerns for the future of Baniwa traditions. He has traveled long distances to warn the indigenous peoples of the dangers in losing their traditions, and he is a religious virtuoso in the sense of accumulating the powers and knowledge of healer shaman, priestly chanter, and dance leader. He has been an important political leader of the community of Uapui for decades, and above all he is internationally recognized for his important work on behalf of the continuity of indigenous religious traditions.

His prophetic message is perhaps best exemplified in The Warnings of Mandu (2008). This Venezuelan film shows what has happened to indigenous communities of the upper Guainia River who have lost their shamanic traditions or whose shamans were manipulated by nonindigenous political interests. The result has been, in Mandu's words, "domination by the enemy," a catastrophic situation foretold in the sacred stories shared by many Arawakspeaking peoples of the region.

ETHNOGRAPHY OF THE BANIWA AND OTHER NORTHERN ARAWAK-SPEAKING PEOPLES

The Baniwa, Kuripako, and Wakuenai are three northern Arawakspeaking peoples living on the borders of Brazil, Colombia, and Venezuela. In Brazil, it is estimated that there are over Ioo villages of Baniwa and Kuripako, with a total population of 4,000; in Colombia, their population is approximately 6,000, predominantly Kuripako; and in Venezuela, the Baniwa and Wakuenai

2 Introduction 


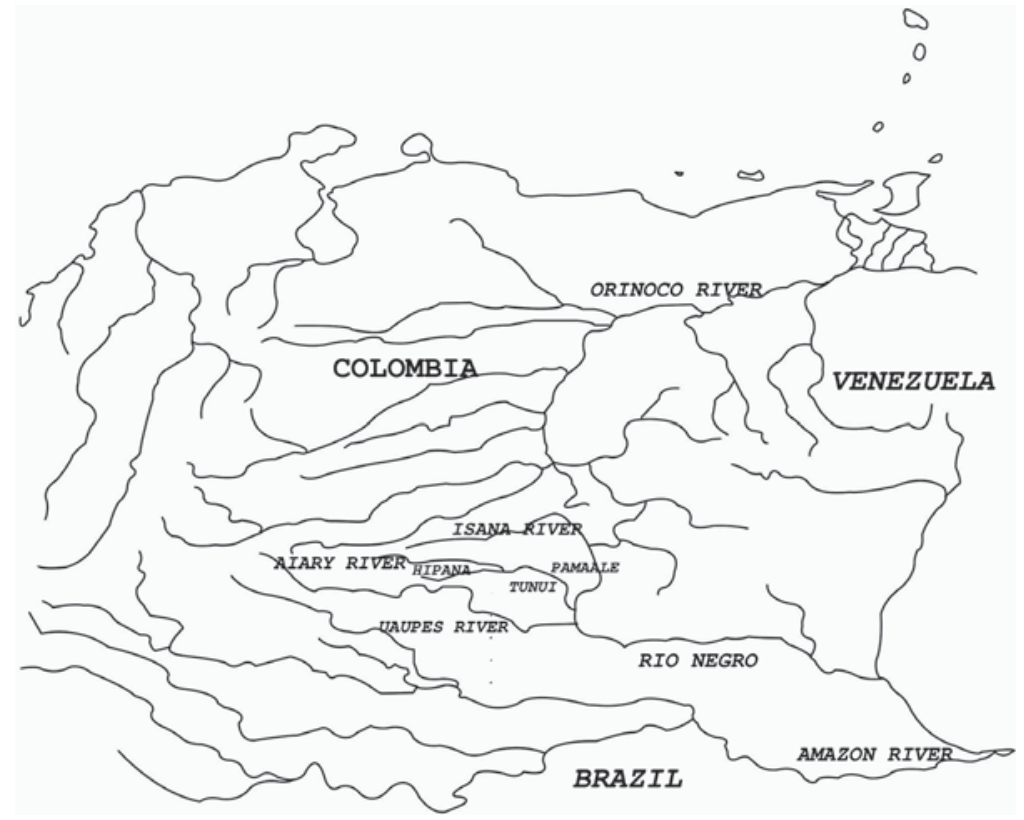

Map I. Northern Arawak-speaking peoples in the Northwest Amazon

(an ethnonym for the Kuripako) together have a population of approximately $\mathbf{I}, 200$.

All of the societies in this region are patrilineal and patrilocal. The Baniwa say that they have three main phratries: the Hohodene of the Aiary River, the Walipere-dakenai of the lower Aiary and most of the middle to lower Içana River, and the Dzauinai on the middle Içana (between the villages of Jui uitera and the hill of Tunui Falls). Beyond the ring of these central groups, there are several small sibs, fragments of other phratries, living in villages further up the Içana.

Each of the principal phratries consists of five to ten sibs, ranked according to a birth order of primordial ancestral siblings who emerged from the earth at the beginning of time in several places, the most important of which is called Hipana, where the universe 
began for the Baniwa and for many other northern Arawak-speaking peoples.

Hipana is a place of great potency, since many world-changing events took place there. The child of the sun was born there. It is considered to be the World Center. The boulders, the powerful flow of water through the narrow passage of the rapids, and the lake below are a place where the first ancestors emerged.

Among the Hohodene, the phratry with whom I did most of my fieldwork, there are five sibs ranked in order of agnatic siblings and ceremonial roles: the first-born is the maku or servant sib, grandparents of the Hohodene; the second-born is the chiefly sib, elder brothers of the Hohodene; the third-born is the warrior sib, the Hohodene themselves; and the two others are younger brother sibs without any clearly defined ceremonial attributes. This ethno-model of phratric creation, however, is one version of a story that varies with almost every narrator. There is no strong consensus on overall sib order in the hierarchy (similarly, among Kuripako in Colombia; see Journet 1995). There is a consensus that the Hohodene, the Walipere-dakenai, and the Dzauinai are the three most important phratries of the Baniwa in the Içana/Aiary River basin. Each of these phratries has its own emergence place (the Walipere-dakenai at Enukwa rapids immediately below Hipana).

The Hohodene mentioned the names of the Aini-dakenai (Waspgrandchildren) and the Hipatanene ("children of the foam of the waterfalls") among the lower-ranking sibs of their phratry. The Walipere-dakenai (Pleiades grandchildren or descendants of the Pleiades) listed upwards of nine sibs in their phratry, with themselves at the head of the constellation Walipere (Pleiades) and the others arranged according to the order of stars in the constellation.

All along the Içana River, from the headwaters down to the Tunui Rapids, the villages are predominantly evangelical Christians, as are most villages of the lower Aiary. Evangelical Christianity was 


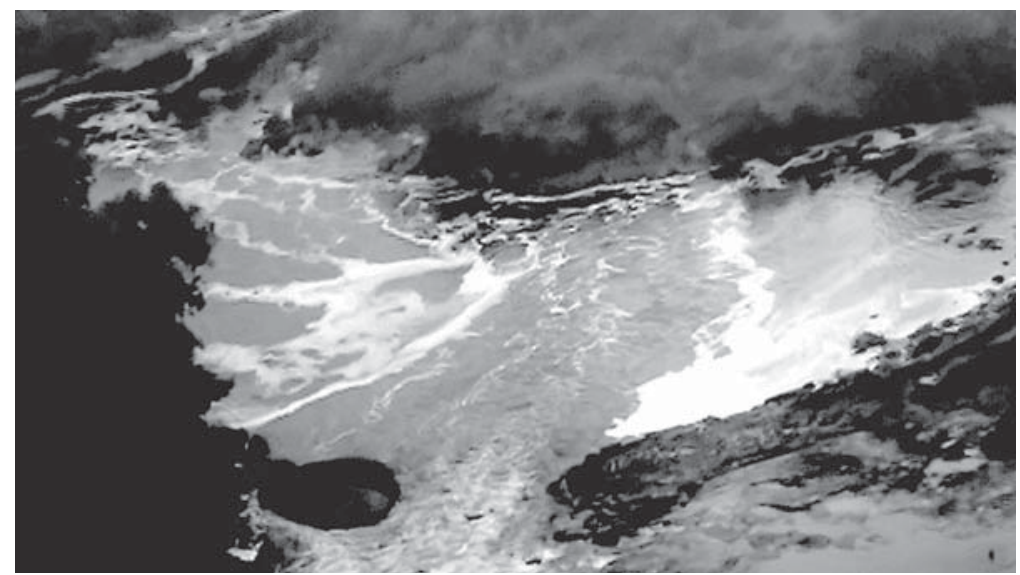

I. Aerial view of Uapui (Hipana) falls, the origin of the universe. (Photo by M. C. Wright, 20IO.)

introduced in the I950s and quickly became a mass conversion movement. It is believed that 80 percent of the Baniwa villagers today are crente, or believers, baptized faithful to the Church. This may be so, considering the introduction of other Protestant churches in the region, such as the Presbyterians and the Baptists, in recent years.

In the early years of the conversion movement, there was bitter fighting between the crentes and the traditionals, the latter consisting mainly of the upper Aiary River villages, especially the two communities of Uapui Rapids and Ukuki Rapids. Uapui is the village built on the banks of the Aiary at the location of Hipana Rapids (which has another name, Kupipani, "house of the cipó Kupi”). Ukuki was built in the late I970s at the rapids of the same name (Kuliriana, in Baniwa) on the Uaraná tributary of the upper Aiary.

For a long time Uapui was a village of shamans-five when I lived there in the I970s. Today shamanism is practically focused only there. The Ukuki community nevertheless has been a solidly 
traditional community in keeping the dance festivals and sacred ceremonies of initiation. In 2008, on their own initiative, they constructed a new longhouse, called House of Adorning, which was basically intended to be a ritual dance house, not a living space. The following year, at Uapui, the community was awarded funds from the Foundation for Shamanic Studies, which enabled Mandu's son and daughter to construct Malikai Dapana (Shamans' House of Power and Knowledge).

“A NEXUS OF RELIGIOUS POWER AND KNOWLEDGE"

The chapters of this book are grouped around five main themes, each of which is part of an entire shamanic tradition. They are (I) a biography of the jaguar shaman Mandu, religious savant and political leader; (2) the problem of sorcery in the communities and other challenges to the continuity of indigenous religious traditions; (3) the interrelations among indigenous cosmology, ecology, and metaphysics of shamanic knowledge and power; (4) the interrelations of sacred geography, petroglyphs, and a body of living mythic traditions; and (5) the viability of transmission and revitalization of shamanic traditions now and for future generations.

The principal Baniwa specialists in shamanic and ceremonial knowledge and power possess distinct attributes and functions, summarized in Table I. This will serve as a guide throughout this book. Each of the four specialists is said to "own" (keep or hold) or "be a master of" a specific kind of knowledge accompanied by certain powers. The term malikai was consistently translated by Mandu as “the pajé's [shaman's] knowledge and power," meaning that the pajé's art does not consist of simply knowing (ianheke), but rather it is knowledge that has creative or protective power inherent to it. One can know a myth, but unless one knows the orations or chants that go along with the story, then one has not yet exercised the power of the knowledge imparted in the myth.

6 Introduction 
When taken as a whole, the different shamanic and ritual "specializations" in "power and knowledge" can be seen to complement each other, forming what I shall call a nexus of (religious) power and knowledge in Baniwa society. The idea of a "nexus" refers to the interrelationship among these bodies of knowledge and power. Each supports or complements the other whether as an oppositional, confrontational type of relation (pajé vs. assault sorcerer), complementary relation as between the pajé healer and priestly chanter (both having to do with the health, well-being, and reproduction of society), or the ritual knowledge and power of ceremonial dancing, which is essential to the production of harmonious conviviality, the way to well-being and happiness, insofar as it celebrates the ties of reciprocity among communities of the same or affinal phratries.

The four principal owners of power and knowledge are

I the pajés (a lingua geral, the old trade language of the region, term for shaman, maliri in Baniwa) who heal and protect their communities, the highest grade of which is the true pajé or jaguar shaman. In this book I shall use the word pajé with greater frequency than the word shaman, except for the term $d z a u i$ malinyai, "jaguar shaman-spirit-others" referring to powerful shamanic spirits of the "Other World."

2 the sorcerers who attack to destroy a victim or an entire family (manhene iminali, poison owner; hiwiathi iminali, owners of assault sorcery chants). These are also called mantís, a lingua geral term for assault sorcerers, and dañeros, a Spanish term for the same thing. From the sorcerers' point of view, their actions are justified as redressing what they perceive to be an imbalance of power or a personal loss that they attribute to sorcery sent by pajés or other sorcerers. 
3 priestly chanters who "own" highly specialized chants called kalidzamai, performed during the all-important rites of passage in which they protect those undergoing life transitions from all potentially harmful places, spirits, and animals in the world.

4 the dance leaders (mandero) who lead the dance lines with the correct patterns for each type of dance, upholding the collective, aesthetic virtues of beauty, symmetry, and form. While the dance leaders have been treated in the literature as owners of a kind of secular knowledge, the term used for their knowledge is manderokai, the suffix -kai referring to the power they have to make the dances effective instruments of sociality. ${ }^{1}$

TABLE I. Religious specialists of northern Arawakan Baniwa

\section{Jaguar Shamans (Maliri, Dzaui Malinyai)}

Training: Io years; involves fasting, abstinence, seclusion, taking psychoactives, constant learning from master; experience of "death" and "rebirth," dismemberment and reshaping of inner self; "marriage" to auxiliary bird-spirits; advanced knowledge to kill; warrior ethos

Calling: sometimes a serious sickness, dream experience, or recommendation from parents; desire to learn; male or female

Powers (malikai): soul-flight; direct experience of spirits and deities in all levels of cosmos; transformation into jaguar spirit (predator and protector functions) and numerous other animal avatars; acquires "body" of jaguar-spirit; jaguar-tooth necklace; curing of sickness; weather control; guides souls of deceased to Other World houses; world-making and healing; hierarchies of power

Attributes: human-animal-spirit; multiple perspectives; double vision; 
sounds thunder; sends soul at will; singing brings Other World into being; considered distinct from sorcerer; rattle is "body and soul" of shaman; numerous "shirts" (subjectivities); "mirrors" allow total, global vision

Characteristics: hunter of souls; master of fire (tobacco); cosmic warrior; cosmic traveler; mediator with deities; master of light (crystals); clairvoyance; diviner

Institutions: schools of instruction of apprentices by master shamans, beginning and advanced levels

\section{Sorcerers (Manbene Iminali)}

Training: informal learning from elder; continued practice until she/ he "owns" knowledge to kill; often part of a faction that seeks to undermine dominant village family or leadership

Calling: often sentiment of retribution due to loss; envy, jealousy, anger, self-exile, desire to destroy those more successful and powerful; in extreme cases the sorcerer sees no end to desire to kill; only thinks of killing

Powers: master of plant and numerous other kinds of poisons and antidotes; seeks to provoke disorder, does harm, sends sickness; de-structures persons, "families," or whole villages; sends soul to transform into predatory animals; physical and spiritual transformation into primordial sorcerer or spirit of deceased

Attributes: extreme secrecy, nocturnal attacks, shape-shifting; killing at a distance; attacks by soul-flight with bone containing poison; may be a member of kin-group or affinal group

Characteristics: serial-killing; victims are elderly, children, young women, successful hunters, successful leaders; increase in attacks during times of social, political, economic change

Institutions: mythically charged geographical locations, or "places of poison" 


\section{Prophets ("Sábios," Kanhenkedali, Savants):}

Calling: already a jaguar shaman and priestly chanter; surviving lethal sickness or extraordinary dream experience or intense trance experience of deceased and/or divinity; often has lived in several ethnic contexts; the Baniwa "await" the appearance of "wise men/women" as protectors, guides, councilors

Powers: clairvoyance; sees future events; battles sorcerers; reveals locations of "poison"; interprets signs of times; extraordinary knowledge of cosmos; converses at will with principal deity and deceased kin; extraordinary power to heal; seeks to build community harmony; dance-leader; powers surpass that of the Whites' military/learned men

Attributes: immortality of soul; return of soul after death to tomb; speaks many languages; prescience; constant communication with divinity

Characteristics: ultra-moral message; anti-sorcery, reformer of society; associated by followers with important deity; considered by following to be immortal; outstanding charisma and translator (resonance with his/her message and what people want to hear); protects community; upholds traditions

Institutions: leader of movements which may become institutionalized ritual forms ("Dance of the Cross," evangelicalism).

\section{Priestly Chanters (Kalidzamai):}

Training: varies, but no more nor less than jaguar shamans

Calling: considered as elder's responsibility (men or women know) Powers: a form of shamanic power, malikai, especially "Thought" journeys (Kuwai ianhiakakawa) in rites of initiation for males and females; protective shamanism with pepper and salt, making food safe for individuals, or families in transition (post-birth, male and female initiation, shaman apprentices, post-mortem); control of ancestral powers to reproduce society; managing the ancestral places and ancestral beings throughout known world, preventing them 
from harming the living; promotes growth of children; chanting over garden for growth and abundance

Attributes: master of canonical knowledge (litanies of names and places chanted in correct order, from beginning to end); lesser chants or whispered formulae (iwapakaithe) for innumerable tasks; using tobacco, remedies, words spoken in closed fist transferred with smoke to materia medica

Characteristics: performs either individually (post-birth, post-mortem) or in groups of 2-4 (initiation, end of shamans' apprenticeship); instruments: sacred ceramic bowl containing pepper and/or salt, cigar

Institutions: no visible connection to institutions or network of chant specialists throughout region; difficulties of learning have reduced numbers

Dance-Leaders (Mandero Iminali): usually elderly men and women who know the songs, the numerous types of dances of the Pudali (festivals of exchange) each with appropriate songs, dance instruments, and dance patterns. There are 24 distinct dances (Costa, 2007: 50) for the Pudali. The sacred rites of the Kwaipan (rites of initiation) are the domain of the shaman and the kalidzamai who are often one and the same person

Training: village elders and/or leaders learn the traditional dances, appropriate adornments, body painting, and dance calendar from previous village leader, traditional chief

Powers (manderokai): The Pudali are occasions of exchange, socializing, celebration of plenty, arranging marriages, much harmonious conviviality, Pakamaratakan (ritual partners) Songs. The pleasure of socializing and dancing together, with great quantities of lightly fermented beverages (padzuwaro) circulating, and the collective sentiment of happiness in the festivals produce harmonious conviviality; dance-leaders enforce the rules of gender separation at times of initiation 
Characteristics: Mandero wears a distinctive acangatara, headdress of white heron feathers, with a long tail down the back, a woven and decorated apron, and the ankle rattles that establish the dance rhythm Attributes: Mandero explains to community the correct dance patterns, starts the dance line in proper rhythm, increases the momentum, establishes the order of dancers and their instruments, leads the forward and backward movements around the offerings (like contracting and expanding circles as though to increase the offering), guards the dance instruments and feather headdresses, and redistributes them at correct time to dance

Institutions: Pudali have been undergoing a revival for at least a decade in four communities of the Aiary River. These same communities have never ceased celebrating the initiation rites, Kwaipan, the most sacred of all rites.

KNOWLEDGE, HIERARCHY, AND AGE

Each form of knowledge and power is acquired at a certain phase of the life cycle: a young adult, male or female, may begin training to become a healer and may either complete the full ten years required to become a "real pajé" or interrupt training at the end of the first major stage and remain a "half-pajé" with limited powers to cure.

Only the senior elderly men and women of the "grandparent" generation can learn the kalidzamai chants, which require great stamina (force, kedzako), memory, exact knowledge of places in the world, and the poetic spirit names (naakuna) of all living beings. There is also less chance that these very elderly specialists are embroiled in any of the struggles that involve shamans and sorcerers, which would detract from the great responsibility and the strenuous spiritual work involved in the transmission of culture through their chanting.

I2 Introduction 
Dance leaders acquire their knowledge from within their own consanguineal kinship groups. As for sorcery, anyone can learn the practice or be an accomplice to a sorcerer, even young children, but the true sorcerers are those whose intentions have become so dominated by the desire to kill as to use poison against everyone whom she or he considers an "enemy." As Mandu stated, "Their only thought is to kill” (manhene kada lima).

The jaguar shaman is a high-level pajé whose power is considered to have been directly transmitted over a long genealogical line from the original creative powers of the universe, especially the deity Dzuliferi, the ancient shaman deity. The jaguar shaman is a "true pajé," considered to "know everything about the world," and is said to be able to attain a place "next to" the place of the creator deity, Nhiãperikuli. She or he is the only native healer who is believed to be capable of curing victims of assault sorcery by poisoning.

The sábios (wise men or women, kanhenkedali tapame) are religious leaders who provide moral guidance to their followers, who include peoples of different ethnic groups spread out over a large geographical area in the Northwest Amazon on three sides of the international borders; who maintain constant communication with the creator deities; and who perform cures or feats that are considered to be extraordinary or miraculous. The sábios combine most of the above named functions into one integrated knowledge and power. Yet, rather than keeping that power centralized in their person, they use their wisdom to protect and benefit the people of their community. In that sense, they are guardians of multiple communities located throughout a wide geographical area and of multiple linguistic groups, demonstrating qualities that are characteristic of the deities Nhiãperikuli and Dzuliferi (the creator deity and the primal shaman, respectively).

The ethnohistories of the Baniwa of the Içana and Aiary and, 
to a certain extent, the upper Rio Negro or Guainia amply testify to the importance of a tradition of wise men and women. These prophetic movements have been (I) regionally based, including indigenous and caboclo (mestiço) peoples of several language groups; (2) continuous from at least the mid-nineteenth century; (3) recalled in oral histories as struggles of the wise men and women against sorcery; (4) most definitely connected to the evangelical movement in the I950s and I960s, which is understood today by evangelical converts as having been instigated by the North American missionary Sophie Muller, who was attributed powers that only a powerful shaman could have to overcome sorcery (Boyer 1999); and (5) most definitely are grounded in the child of the sun, Kuwai, traditions (Wright 2005).

There is no historical evidence to argue that any of these wise people were of a "horizontal" or "vertical" type of shamanism, as has been discussed for the Tukanoan-speaking peoples (Hugh-Jones 1996; Viveiros de Castro in Chaumeil 2003: 38). The stories the Baniwa tell about these extraordinary people confirm that they were jaguar shamans, dance leaders, and chanters who were particularly concerned with the problem of sorcery, encouraging their followers to live in harmony, free of sorcery, and who utilized their formidable powers of prescience to benefit the people. They have been strongly against using secular political power for their own ends.

\section{SENSE OF MYSTERIES}

According to Baniwa traditions, sickness and sorcery were introduced into This World at the end of the first initiation ceremony by the great spirit "owner of sickness," Kuwai, about whom a significant part of this book is dedicated. The "mysteries of the jaguar shamans" revolve around this world-creating being, who is the "child of the sun father," Nhiãperikuli, the Baniwa creator deity, and the first woman, Amaru. There are numerous other mysteries

\section{I4 Introduction}


in the sense of "hidden things" - the Unknown in Baniwa cosmology, sacred rites and narrative, and above all, shamanic practices. None, however, commands the secrecy and the force that the Kuwai traditions did and in some places still do.

How then do the jaguar shamans teach and transmit these mysteries to apprentices among a larger community of northern Arawak-speaking peoples? How do they make known the Other World of spirits and deities which they must experience directly in order to realize a cure? In our exploration of the features, qualities, and dimensions of the Other World, we shall consider shamans' songs, exegeses of sacred narratives, healing practices, and protective actions against sorcerers.

The knowledge and power of the shamans today ultimately derives from the primordial owners, the great spirits and deities who brought everything in This World into being. Anyone can learn the stories about them; they are considered "good to hear" and reflect upon. The powers they explain, however, are the basis of chants, songs, and prayers. These can be learned and transmitted only by people who are properly instructed in their use. To speak the words of an oration, chant, or prayer can be beneficial in healing, providing food, and making gardens grow well. They are protective in warding off potential dangers or attacks by sorcerers or spirits. By the same token, they are believed to be extremely dangerous in harming or even killing a person. In all these senses, malikai knowledge and power should be learned and used with great caution. One of the problems that the Baniwa face today is that, with the extreme reduction of their true pajés, the sorcerers' power to harm can become uncontrolled.

The greatest challenge in doing ethnography for this kind of book was in empathizing with the pajé's perspective, particularly when their heart-souls (ikaale) are said to be journeying in the Other World (Apakwa Hekwapi). This requires close attention to 
specific linguistic forms and the poetry of the shamans' songs, which can be understood as constitutive of their soul-flight and their encounters with the great spirits and deities of the Other World. Like Kuwai, the jaguar shamans can assume multiple shapes and forms in their journeys to the Other World. The pajé's body and soul become totally "other" (a jaguar shaman spirit, not human), and they acquire the resources uniquely capable of combating sorcery and sickness-giving spirits.

In order to cure the sick, the pajés soul must visit the "netherworld of the dead" (Hill 1993). Actually, for the Baniwa jaguar shamans, their souls should visit all of the five "Houses of the Souls of the Dead" pertaining to the principal phratries of the Baniwa. But this is just the beginning of their search; from there, their souls travel "upstream" to various places in the Other World of the sky, where different deities are said to have their houses. The voyage we try to reconstruct in chapter 2 is based on curing sessions taped and translated over many years with the help of shamans' apprentices.

\section{DEALING WITH SORCERY}

Chapters I, 2, and 3 concern the apprenticeship of the jaguar shaman Mandu da Silva and his struggles against the actions of several sorcerers in the village of Uapui, Aiary River. Pajés and mantís are opposing forces at either end of a gradient that separates good people (matchiaperi) from the wicked (maatchipem). To understand the struggles between them, it is vital that we take into account the motives behind the sorcerers' actions. To what extent have external influences on Baniwa society resulted in disruption and increases in assault sorcery attacks?

One of the principal objectives of the historical prophets, wise men and women, has been to control sorcery-by-poisoning, by transforming the negativity that permeates villages where sorcery 
has become dominant into harmonious conviviality. The prophets' powers are considered to be greater than the jaguar shamans' because they are practically the living voices of the deities and maintain an open line of communication with the creator. Chapter 2 presents material about the historical prophet Uetsu, who, like Mandu, battled much of his life against sorcerers (see also Wright 2004a). It is instructive to compare their campaigns to control sorcery and at the same time defend sacred traditions.

\section{THE BEGINNING OF SORCERY}

For the Baniwa, assault sorcery has existed since the beginning of the Universe. When the creator deity sought a better condition than the existing static and sterile condition of eternal Daylight, he ultimately let Night out of a small basket in which it was contained, forcing the sun to fall outside the sky vault of This World. Night covered the world, then miniature, in darkness. By bringing Night into existence, the creator deity made two distinct and equal states of living reality: Day (for work) and Night (for rest). This was good. The light of the Day divided time and space with the Darkness of the Night. Time was set into cyclical motion, two equal states of being.

It was a long, dark night, however, that brought "sadness" with it, for each being had to go its own separate way to find a place to sleep. During the first long night, sorcery came into being. The first woman, the creator's wife, began throwing "poisonous ants" (tocandira) in the direction of the tree where the creator was keeping vigil. The creator transformed each of these ants into harmless insects. When the Dawn appeared, Happiness returned, for a new Universe and a new Day had begun (day and universe are the same word, hekwapi). Day and Night, Light and Dark, Happiness and Sadness, Life and Death - all of these came into being with the knowledge and powers of pajés and sorcerers. The Story of Night is one of the first stories of creation. 
The existence of the sorcerers is one of the all-time dilemmas for the Baniwa. The sorcerers' powers are necessary to keep in check social, political, and economic inequalities. In a society that highly values a relatively egalitarian ethos, anyone who accumulates power and knowledge becomes vulnerable to the "leveling mechanism" that assault sorcery represents (Whitehead \& Wright 2004; Garnelo 2003).

Sorcery can come to dominate a practitioner's body and soul, with dramatic consequences for the entire village, placing its very survival in danger. The sorcerer becomes a "serial killer" - or at least the whole village believes this to be so. Such has been the history of numerous villages in the past, which the Baniwa recall and outside published sources have recorded (Koch-Grünberg I967 [1909); Wright 1998).

As Mandu stated in the film Las Advertencias de Mandú (The Warnings of Mandú) aired on Venezuelan national television several years ago, "If the sorcerers triumph, then chaos will prevail; for then the people and, with them, their traditional indigenous culture will be exterminated [producing a void that leaves the indigenous area open to] "the expansion or domination by the white people" (my translation).

The film, winner of the Venezuelan Ministry of Culture's Yulimar Reyes National Documentary Competition, has had positive repercussions on cultural revitalization and the historical memory of the native peoples of the town of Maroa, on the Rio Guainia, in Venezuela. Above all, the film called on communities who had left their ancestors' ways of life behind, to attempt to revitalize them, denouncing the nonindigenous politicians who were using powerful shamans to support their political campaigns.

Fluctuations in the incidence of sorcery can be linked to interventions by peoples seen as "outsiders" (sorcerers, white people) in Baniwa communities. These outsiders have produced situations 
of unequal distribution of power and knowledge, thereby creating tensions and conflicts that are propitious grounds for sorcery accusations and social transformations.

In the mid-twentieth century, for example, the Baniwa and Kuripako hoped to eliminate the "problem of sorcery" by converting en masse to fundamentalist evangelicalism (see Boyer 1999; Saake 1959-60a; Wright 1998, 2005) introduced by the North American missionary Sophie Muller. Today, however, the evangelicals speak of an increase in assault sorcery in their communities despite their having abandoned all, or most, of their most sacred ancestral traditions. Evangelicalism failed to provide an adequate, alternate solution for the continued existence of sorcery in the world, one not based on the sacred narratives which the evangelicals condemned. The Baniwa evangelicals had definitively abandoned the sacred ceremonies, along with the practice of the jaguar shamans, the only specialists who could cure cases of poison. The age-old mystery of how the universe came to be the way it is today is for the evangelicals no longer a secret.

Nevertheless, they continue to explain death as the result of unknown enemy sorcerers, even from within the same community. This is a stark demonstration that, in giving up shamanic practices, they created a vacuum that has been extremely difficult to overcome. Shamans are the only specialists who are trained to "see" (recognize) who the sorcerers are in a community and to combat them on a cosmological level.

Since the 1980s, NGO health programs have encouraged the evangelicals to train indigenous health agents and to plant medicinal gardens near their homes. Western biomedical practice and workshops, based on an entirely distinct logic, could not provide a convincing explanation either for what the Baniwa had for centuries understood as sorcery by poisoning or even attacks by forest spirits. These require the pajés' soul journeys to cure or 
knowing highly specialized chants, which implies a knowledge of the cosmos, the spirits and deities who dwell in it, their powers, and how to enlist their help in the healing of the sick.

As one young shaman perceptively observed, the indigenous peoples have sicknesses that Western biomedicine cannot even diagnose. For that reason, abandoning shamanism, as the crentes did, was a grave error. By contrast, pajés recognize Western biomedicine as complementing their own practice in the sense of treating ailments that are believed to be transmitted by or sent by the white people; also, modern medicine utilizes instruments such as X-ray technology that is similar to the pajés' power to "see" inside the body of the patient to locate the source of the sickness. However, Western biomedicine can interfere with shamanic treatment, for example, by altering the body (orthoplasty) in some way, making shamanic treatment more difficult.

\section{COSMOLOGY AND ECOLOGY}

To have a better understanding of the dynamics of sorcery and shamanic practices, we are led to cosmologies and their ecological foundations. Thus chapters 3 and 4 present the universe through an ecological metaphor. Animals, birds, and celestial bodies of major importance in the Baniwa cosmos are placed by pajé interlocutors in their correct positions on an enormous cosmic Tree at the center of the universe, Hipana, that is, the vertical axis of the cosmos. Through this metaphor, we can better understand the pajés' visions of the cosmos, the nature of existence, and their visions of the sources of good and evil in the world. The origin of the pajé's powers is intimately connected to the food cycles of the cosmos; at the same time that humanity received all food resources, the pajés received their powers to mediate between worlds. The pajés have a vital role in guarding the food resources in This World.

On the horizontal plane, the entire Northwest Amazon region 
is populated by the memories of what the deities and primordial beings did and where they walked and inscribed images on the stones, known as petroglyphs. Through the chants sung during rites of passage, the sacred sites, and the memories of the elders, the entire region has a long tradition that connects present-day descendants to their ancestors. This "mythscape" is, in its totality, an open book of Baniwa cosmic history, an ever-present reminder of how This World came to be. More than that, the ecology is sacred in that the stones themselves are said to be the dwelling places of both spirits and deities, houses of the souls of the dead, of animals, of fruits and other food resources. There are at least five major sacred sites in this mythscape that can be seen to represent the endpoints of the entire Baniwa universe on the horizontal plane.

The Kuwai traditions are the equivalent of the popularly known Yurupary cults. The word Yurupary refers to a Tupian demiurge of the forest, but was introduced to the Northwest Amazon region possibly in the mid-nineteenth century, when Capuchin missionaries began to work on the Uaupés River south of the Içana and Aiary. The missionaries used the term in the sense of a demon of the forest, while the Tupian thunder god Tupã was used as a lingua franca term for God, reducing the multiple names for deity of the more than twenty ethnic groups to one exogenous deity which, for the indigenous peoples of the Northwest Amazon, had little or no relation to their deities. The name Tupã stuck, however, representing the colonial missionary God up until very recently when the different ethnic groups began publishing their sacred stories with the correct names of their deities.

The Yurupary tradition became the object of persecution by the missionaries from the late nineteenth century until recently. Again on the Uaupés River, Franciscan missionaries defiled sacred masks, which were believed to be the forest demon whose actual name was Kue for the Tariana Indians (Arawak-speaking), the 
equivalent of the Baniwa Kuwai. For the Baniwa, Kuwai refers to the sacred ancestral flutes and trumpets which are believed to be the body of the original Kuwai, the great spirit child of the sun, owner of sickness, also known as Wamundana, whom the pajés see in their soul journeys to the Other World.

The sacred flutes and trumpets have always been central to Baniwa notions of spirituality, cultural transmission, health and sickness, shamanic practice, and ecology, as they are for most other northern Arawak-speaking and eastern Tukanoan-speaking societies of the Northwest Amazon. ${ }^{2}$ The sacred stories and rituals of Kuwai are intimately connected with shamanism and ceremonial traditions (healing, sorcery, initiation chants, and ritual dances), seasonal fertility, ecological cycles, and the souls of the first ancestors.

According to Reichel-Dolmatoff, it is very likely that the "Kuwai traditions" are Arawak in origin and that the ancient northern Arawak-speaking peoples (such as the Maipure) had a strong influence on similar traditions among the Tukanoan-speaking peoples of the Uaupés River and its tributaries to the south of the Baniwa (Reichel-Dolmatoff 1996).

In fact, the Kuwai traditions form a vast "mythscape" of "sacred sites" and "sacred geography" in Baniwa territory, discussed in chapter 5. These sites include petroglyphs, waterfalls, caves, hills, and numerous other landscape features, where significant events told in the sacred story of Kuwai took place. The chants sung at initiation rites re-create this mythscape in minute detail, encoding multiple layers of meaning all of which refer to the world-opening, all-encompassing, transformational spirit who is the child of the sun father and the first woman.

The spatial extensiveness and the temporal depth of the "Kuwai Religion," as these traditions have been called (Vidal 1987), connect living peoples' identities to their ancestral lands. To the Baniwa/ Kuripako/Wakuenai who continue to believe in these traditions, 
the petroglyphs are evidence that their ancestors really were there, and that events in the stories really did take place. The ancestors left these memories for their descendants (walimanai) to learn from and live by. The greatest loss imaginable will come when the younger generation no longer knows the meanings of these traditions, which is already a sad fact in many communities.

Chapters 6 to 8 present a complete version of the sacred story of Kuwai, and discuss its intimate relationship to jaguar shamanism. My discussion of the story in three chapters coincides with the major episodes: the birth of Kuwai, the first initiation rites, and the struggle for ownership of the sacred flutes and trumpets, Kuwai's body.

The story unveils a "worldview, in the Diltheyan sense of the term, one which is grounded in an ideally balanced relation with the natural world. Jaguar shamans have a particularly deep understanding of this tradition, since it is to Kuwai that their souls must travel in order to realize a cure. Through the pajés' exegesis on Kuwai, and all things related to this figure, we can appreciate the mysteries of this paradoxically creative and destructive spirit.

The terms that Victor Turner used several decades ago of liminality and "semantic multivocality" (1995 [1969]), are particularly appropriate for understanding how layers of meanings, which may seem paradoxical to us, are integrated into the same being of Kuwai. Kuwai's multiplicity of forms and complexity of meanings all are part of the knowledge and power (malikai) of the pajés as well as of all peoples who have been initiated.

Kuwai is an extraordinary being, the child of the creator deity Nhiãperikuli with the first woman, Amaru. Nhiãperikuli wanted a child that was the product of his shamanic thought (ianheke) and that was the reproduction of his "heart-soul," the most lasting element of a person's being. By shamanic means, Nhiãperikuli brings into being a child of his heart-soul. Kuwai was a very strange 
creature: his body was full of holes that emitted the sounds and melodies of numerous animal parts of his being. This mixture of so many animal parts into one was exceedingly dangerous to humanity, forcing Nhiãperikuli to banish the child to the sky world.

This brief description is sufficient for now to understand that the story of Kuwai is about the transmission of shamanic knowledge and power. All of Kuwai's body is directly related to shamanism and growth. The growth of young children into adults and the apprenticeship of shamans require the materialization of the mysterious cosmic power of transformative change which Kuwai embodies and which is represented by the sacred ancestral flutes and trumpets.

Kuwai is growth: of the world, of the initiates, which he transforms through the power of his music. Yet as a protean type of spirit, it was too dangerous to allow him to stay in This World. Upon learning all his knowledge, at the end of the first initiation ceremony, his father pushed him into an enormous fire. He never died, though, for his spirit continues to live in the Other World. In our interpretation, we show how the "death" of Kuwai meant the incorporation of all his knowledge of the spirit world and its power as well into society. From his body came all of the forms of sorcery and sickness-giving spirits, such as the Yoopinai. From his body also came the first tree from which the sacred flutes and trumpets, which are his body, were made. With it, the men would reproduce future generations.

\section{A TRADITION IN THE BALANCE}

The Baniwa say that traditionally, there was at least one pajé, and often several, in each of their villages. Due to the evangelical crusades and their destruction of shamanism in the 1960s and I970s, the number of pajés did not surpass much more than a dozen

\section{Introduction}


when I began my field research in 1976. As time passed, the elder "true pajés" died without having transmitted their power and knowledge on to their direct descendants who did not want to learn the traditions or were away from their homes; thus the situation became even more critical.

In 2009, among all Baniwa/Kuripako in Brazil at least, there were only two "true pajés" who had advanced knowledge, one of whom, Mandu da Silva, is a jaguar shaman and a priestly chanter. Many followers of Mandu also consider him to be a "wise man" or prophet. There are several "half-shamans" in Uapui village who have acquired the basics of the practice but do not yet have "advanced knowledge."

As a result of a project initiated by the adults of the village of Uapui to revitalize jaguar shamans, apprentices recently began instruction. There are perhaps five pajés and six apprentices on the Aiary River today, which is an area known for always having defended the traditions (from forced acculturation by the missions).

When Mandu da Silva passes on to the Other World, an entire corpus of living knowledge about the universe, the spirits, the plants, old shamans, and so much more will no longer be making worlds as when he was alive. This book, then, attests to the importance of his knowledge and powers for the Baniwa themselves and for others, providing a dual view from an anthropological interpretation and indigenous insight on how jaguar shamans compare with the other main forms of religious knowledge and power in Baniwa culture-except for evangelical Christianity (which is being researched by very competent fieldworkers amongst the Baniwa and Kuripako of the middle and upper Içana River).

Whether the new "House of Shamans' Knowledge and Power," Malikai Dapana as it is called, built in Uapui in 2009, will have continuity is a question discussed in the final chapter of this book. The idea came from the young leaders, especially the schoolteachers, 
but the House will surely be utilized for holding large festivals, such as those that Mandu describes in his autobiography.

\section{RESEARCH}

Since 1976, and especially over the past several years, my relationship with Mandu has been much like that of master and apprentice, except that I have been unable to follow up with his suggestion to complete the first stages of apprenticeship, which involve a month of seclusion, ingesting numerous kinds of "medicine" (-tápe), and constant inhaling of the psychoactive snuff called pariká.

Pariká is a crystalline powder made from the blood-red exudates of the inner bark of Virola theidora and Anandenanthera peregrina trees found in the Northwest Amazon region. Its active chemical principle is DMT (dymethyltriptamine). The more experienced pajés sometimes use a mixture of pariká and another hallucinogen known as caapi (Banisteriopsis caapi). The only way to become a "true pajé" with advanced knowledge of jaguar shamans, Mandu said, is to endure prolonged fasting and the constant use of pariká until one's vision is transformed and one "sees the way the pajés see and feel the way they feel in the Other World."

In 1976-77 I studied with Mandu's uncle, who also was a wellknown pajé and chief of Uapui village for over a generation. José Garcia, the son of the "wise man"/jaguar shaman Guilherme Garcia, about whom Mandu speaks often in his biographical narrative, also taught me a little of what he knew; even that "little," however, was enormously instructive. Another pajé, Edu, introduced me to pariká in 1977. I have observed innumerable curing sessions and have been a patient in one cure.

The research for this book began in 1997 and became more intensive over the past three years through weekly telephone conversations with Mandu and his daughter Ercilia, who translated and wrote down her father's knowledge of shamanic powers. She 
was as interested as I to know her father's life and his struggles, and she became an avid student, taping as he sang, filming as a group of shamans made pariká, and filming a curing rite.

The material on cosmology and sacred stories has been researched for thirty-five years and most intensively during the production of Wisdom of Our Ancestors (Waferinaipe Ianheke, 1999), a book in Portuguese with a great many of the sacred stories of creation, as well as minor stories of forest spirits and even texts of shamanic experiences in apprenticeship. During the years 2000-2002, while collaborating in a research project on public health questions among the Baniwa, I interviewed Mandu in depth about his knowledge of assault sorcery. Above all, over the past two years, Mandu and his daughter have been most interested in recording his extensive knowledge as the first part of the project of the Malikai Dapana. 